\title{
Analisa pengaruh temperatur pemanasan pada proses normalizing dan hardening quenching terhadap kekuatan tarik dan struktur mikro baut ST-60
}

\author{
Sutrisno $^{1^{*}}$, Azmal ${ }^{2}$, Dwi Handoko ${ }^{3}$ \\ 1,2,3 Jurusan Teknik Mesin, Politeknik Negeri Pontianak \\ Jln. Jenderal Ahmad Yani, Bansir Laut, Pontianak Tenggara, Kota Pontianak, Kalimantan \\ Barat 78124 \\ ${ }^{*}$ Corresponding author: idris_tris@yahoo.com
}

\begin{abstract}
This study aims to obtain information about the price of tensile, hardening, and changes in microstructure as well as changes in material properties at hot temperature variations $800^{\circ} \mathrm{C}$ to $900^{\circ} \mathrm{C}$. The method used in this study is an experimental method, where the material used is ST-60 steel bolts, with a tensile test sample form referring to the ASTM D 638-03 standard, while for testing hardness and chemical composition based on machine standards, namely $\emptyset 16 \mathrm{~mm} \times 20 \mathrm{~mm}$. In this study, 5 samples were made at each temperature of $0^{\circ} \mathrm{C}, 800{ }^{\circ} \mathrm{C}, 850{ }^{\circ} \mathrm{C}, 900{ }^{\circ} \mathrm{C}, 950{ }^{\circ} \mathrm{C}$ and $1000{ }^{\circ} \mathrm{C}$ with the type of heat treatment in the normalizing process and the hardening quenching process. This research was conducted in the Laboratorium Pengujian Bahan, Jurusan Teknik Mesin, Politeknik Negeri Pontianak. The test results on the normalizing process for tensile strength decreased by an average of 230.78 $\mathrm{N} / \mathrm{mm}^{2}$ or $50 \%$, Vickers hardness decreased by an average of $33.99 \mathrm{HV}$ or $31 \%$ and the carbon content decreased by an average of 0.19 or $48 \%$ of the normalizing process is not done. Whereas in the hardening quenching process, the average tensile strength increased by $93.22 \mathrm{~N} / \mathrm{mm}^{2}$ or $20 \%$, the Vickers hardness on average increased by $19.29 \mathrm{HV}$ or $18 \%$ and the average carbon content increased by 0.06 or up $17 \%$ of the hardening quenching process was not done. So to overcome the decrease in mechanical strength and changes in the microstructure of the ST-60 bolt due to hot temperatures, the hardening quenching process can be applied, namely by polishing with used oil after the bolts work at hot temperatures.
\end{abstract}

Keywords: ST-60 bolt material, heat treatment, mechanical strength, chemical composition.

\begin{abstract}
Abstrak
Penelitian ini bertujuan untuk memperoleh informasi tentang harga kekuatan tarik (tensile strength), kekerasan, dan perubahan struktur mikro serta perubahan dari sifat bahan pada variasi temperatur panas $800^{\circ} \mathrm{C}$ sampai $900^{\circ} \mathrm{C}$ proses normalizing dan proses hardening quenching. Metode yang dilakukan pada penelitian ini adalah metode eksperimen, dimana bahan atau material yang digunakan adalah baut baja ST-60, dengan bentuk sampel pengujian tarik mengacu standar ASTM D 638-03, sedangkan untuk pengujian kekerasan dan komposisi kimia berdasarkan standar mesin yaitu $\varnothing 16 \mathrm{~mm}$ x $20 \mathrm{~mm}$. Pada penelitian ini sampel dibuat 5 sampel setiap temperatur $0^{\circ} \mathrm{C}, 800^{\circ} \mathrm{C}, 850^{\circ} \mathrm{C}, 900^{\circ} \mathrm{C}, 950^{\circ} \mathrm{C}$ dan $1000^{\circ} \mathrm{C}$ dengan jenis perlakuan panas pada proses normalizing dan proses hardening quenching. Penelitian ini dikaukukan di Laboratorium Pengujian Bahan Jurusan Teknik Mesin Politeknik Negeri Pontianak. Adapun hasil pengujian pada proses normalizing untuk kekuatan tarik menurun rata-rata sebesar $230,78 \mathrm{~N} / \mathrm{mm}^{2}$ atau $50 \%$, kekerasan Vickers menurun rata-rata sebesar 33,99 HV atau $31 \%$ dan kandungan kadar karbon menurun rata-rata sebesar 0,19 atau $48 \%$ dari tidak dilakukan proses normalizing. Sedangkan pada proses hardening quenching untuk kekuatan tarik rata-rata naik sebesar 93,22 $\mathrm{N} / \mathrm{mm}^{2}$ atau $20 \%$, kekerasan Vickers rata-rata naik sebesar 19,29 HV atau $18 \%$ dan kandungan kadar karbon rata-rata naik
\end{abstract}


sebesar 0,06 atau naik $17 \%$ dari yang tidak dilakukan proses hardening quenching. Jadi untuk mengatasi terjadi penurunan kekuatan mekanik dan perubahan mikro struktur pada baut ST-60 akibat temperatur panas, maka proses hardening quenching dapat diterapkan, yaitu pemolesan dengan oli bekas setelah baut bekerja pada temperatur panas.

Kata kunci: bahan baut ST-60, perlakuan panas, kekuatan mekanik, komposisi kimia.

\section{Pendahuluan}

Perkembangan penggunaan mesinmesin di industri selalu menyesuaikan teknologi terbarukan dengan memperhatikan kuantitas dan kualitas mesin-mesin yang digunakan, sehingga produk yang dihasilkan sesuai dengan standar yang diinginkan. Dalam proses produksi kesalahan dan cacat dalam produksi salah satu diakibatkan oleh bahan komponen mesin yang tidak mampu karena dipengaruhi oleh beban dan temperatur kerja mesin itu sendiri.

Untuk menghindari kegagalan yang terjadi pada komponen mesin salah satunya baut pengikat, maka perlu ada upaya perbaikan untuk menimalisir kerusakan yang terjadi pada baut disebabkan oleh temperatur panas terjadi pada saat mesin bekerja, yaitu melalui penelitian pengaruh temperatur panas terhadap kekuatan mekanik dan struktur mikro material baja baut yang digunakan. Sehingga kualitas material tersebut memenuhi persyaratan seperti ketangguhan, kekuatan, keuletan, kekerasan, dan ketahanan, misalnya tahan terhadap beban tarik karena perubahan temperatur sehingga kerja mesin dapat terjamin.

Lebih dari $75 \%$ kegagalan material pada konstruksi mesin adalah akibat kelelahan atau fatik [1], dan dalam penggunaannya pengaruh suhu terhadap material cenderung akan mempengaruhi struktur metalurgi material tersebut yang merupakan salah satu faktor penyebab terjadinya kegagalan pada material [2]. Sedangkan penelitian yang telah dilakukan oleh James Marrow [3] pada pengujian impak terhadap baja karbon dan Aluminium yang memperlihatkan dua buah skema kurva transisi ulet ke getas antara baja karbon dan Aluminium. Hasil dari kedua kurva tersebut menunjukkan perbedaan transisi dari ulet ke getas yang sangat nyata, untuk baja karbon transisi sangat terlihat tajam dibandingkan Aluminium.

Penelitian telah mendapatkan gambaran data tentang kekuatan mekanik (kekuatan tarik dan kekerasan) dan sifat bahan karena perubahan struktur mikro akibat dari perubahan temperatur pada material baut baja dengan berbagai kondisi operasional. Dalam penelitian ini material baut baja yang digunakan adalah material baja ST-60 dipanaskan didapur pemanas dengan jenis perlakuan panas normalizing dan hardening quenching pada variasi temperatur dari $800^{\circ} \mathrm{C}$ sampai $1000^{\circ} \mathrm{C}$ dan dilakukan pengujian kekuatan tarik, kekerasan dan komposisi kimia. Sehingga akan didapatkan berapa besar perubahan kekuatan mekanik dan sifat mekanik akibat pengaruh temperatur panas pada baut ST60.

\section{Tinjauan Teoritis}

Baja adalah logam paduan besi (Fe) sebagai unsur dasar dan karbon (C) sebagai unsur paduan utamanya. Kandungan karbon dalam baja berkisar antara 0,2 2,1\% dari berat grade-nya. Fungsi karbon dalam baja adalah sebagai unsur pengerasan pada kisi kristal atom besi. Baja karbon adalah baja yang mengandung karbon lebih kecil 1,7 \%, sedangkan besi mempunyai kadar karbon lebih besar dari $1,7 \%$. Baja mempunyai unsur-unsur lain sebagai pemadu yang dapat mempengaruhi sifat dari baja. Penambahan unsur-unsur dalam baja karbon dengan satu unsur atau lebih, bergantung pada karakteristik baja karbon yang akan dibuat [4].

Perlakuan panas adalah suatu proses merubah sifat mekanis dengan cara 
mengubah struktur mikro melalui proses pemanasan dan pengaturan kecepatan pendinginan dengan atau tanpa merubah komposisi kimia yang bersangkutan.

Heat Treatment (perlakuan panas) merupakan suatu proses pemanasan dan pendinginan pada logam untuk mendapatkan sifat-sifat tertentu yang diperlukan untuk suatu konstruksi kekuatan, kelunakkan dan memperhalus ukuran butir. Perlakuan panas ada beberapa jenis yaitu hardening, tempering, quenching, dan annealing. Menurut Purwaningrum [5], perlakuan panas mempunyai tiga dasar yaitu heating, holding, cooling. Heating merupakan pemanasan sampai diatas atau dibawah temperatur kritis suatu material. Holding merupakan penahanan material pada temperatur pemanasan untuk memberikan kesempatan perubahan struktur mikro. Cooling merupakan pendinginan dengan kecepatan yang diinginkan.

Menurut Amanto [6], annealing dapat didefinisikan sebagai pemanasan pada suhu yang sesuai, kemudian diikuti dengan pendinginan pada kecepatan yang sesuai. Hal tersebut mempunyai tujuan untuk menginduksi kelunakan, memperbaiki sifat-sifat pengerjaan dingin, dan membebaskan tegangan-tegangan pada baja sehingga diperoleh struktur yang dikehendaki. Menurut Dieter [7], proses annealing merupakan proses perlakuan panas untuk menghasilkan perlit yang kasar (coarse perlite) tetapi lunak dengan pemanasan sampai austenisasi dan didinginkan secara perlahan-lahan dalam tungku pemanas (furnace), dengan tujuan untuk memperbaiki ukuran butir serta dalam beberapa hal juga untuk memperbaiki machin- ibility. Disamping itu juga pelunakan dilakukan untuk tujuan meningkatkan keuletan dan mengurangi tegangan dalam yang meyebabkan material berperilaku getas [8].

Proses pemanasan dan menjaga pada temperatur austenisasi pada perlakuan panas hardening berfungsi untuk melarutkan sementit yang terdapat dalam austenit yang kemudian dilakukan dengan proses quenching. Quenching adalah proses pencelupan baja dengan laju proses pendinginan sangat tinggi yang berada pada temperatur pengerasannya (temperatur austenisasi) [9].

Normalizing adalah jenis perlakuan panas yang berfungsi untuk memperhalus butir, menghilangkan tegangan sisa, memperbaiki mampu mesin, dan memperbaiki sifat mekanik pada baja karbon struktural atau pada baja paduan rendah. Proses normalizing diterapkan pada produk tempa yang besar, over-heated forgings dan produk cor. Normalizing terdiri dari proses pemanasan baja diatas temperatur kritis, kemudian ditahan pada temperatur tersebut dalam waktu tertentu menyesuaikan dengan jenis dan ukuran baja. Proses tersebut dilakukan hingga terjadi transformasi fasa pada seluruh bagian material, kemudian dilakukan proses pendinginan menggunakan udara $[7,8]$.

Tempering adalah proses memanaskan kembali baja yang sudah dikeraskan yang bertujuan untuk meningkatkan keuletan atau duktilitas, namun menurunkan tingkat kekerasan dan kekuatannya. Pada baja struktur, tempering dilakukan untuk mendapatkan sifat kombinasi antara keuletan, kekuatan dan ketangguhan yang tinggi. Oleh karena, proses tempering yang dilakukan pada baja setelah proses hardening akan menghasilkan baja dengan sifat struktur yang lebih stabil $[7,8]$.

Tempering mengurangi kerapuhan, tetapi juga melunakkan baja, yang tidak bisa Anda hindari. Namun, jumlah kekerasan yang hilang dapat dikontrol dan tergantung pada suhu Anda melakukan baja selama proses penempaan. Itu berlaku untuk semua baja kecuali baja berkecepatan tinggi; tempering meningkatkan kekerasan baja berkecepatan tinggi $[7,8]$.

Proses Anealing diterapkan untuk memperbaiki sifat mekanik baja struktural dengan proses hardening dan kemudian diikuti dengan proses tempering. Proses 
Anealing terdiri dari beberapa tipe dengan karakteristik dan sifat tertentu antara lain Full Annealing, Spheroidized Annealing, Isothermal Annealing [7,8].

Case Hardening adalah perlakuan panas yang ideal untuk material atau komponen yang membutuhkan permukaan tahan aus dan inti yang kuat, seperti roda gigi, lengan silinder, cams, dan sebagainya. Proses case hardening yang paling sering digunakan yaitu karburisasi dan nitridasi $[7,8]$.

Selama proses perlakuan panas case hardening, baja karbon rendah dipanaskan hingga mencapai suhu spesifik, kemudian bagian tersebut didinginkan dengan cepat, permukaan luar atau casing menjadi keras, namun memiliki bagian dalam yang lunak tapi sangat tangguh $[9,10]$.

Kekuatan tarik(tensile strength, ultimate tensile strength) adalah tegangan maksimum yang bisa ditahan oleh sebuah bahan ketika diregangkan atau ditarik, sebelum bahan tersebut patah. Pengujian tarik merupakan salah satu pengujian yang penting untuk dilakukan, karena dapat memberikan berbagai informasi mengenai sifat-sifat baja [11-16].

Pada penelitian ini untuk mengetahui kekuatan mekanik baut ST-60 dengan variasi temperatur panas $600{ }^{\circ} \mathrm{C}$ sampai $900{ }^{\circ} \mathrm{C}$ dilakukan pengujian tarik dengan mesin uji "Universal Testing Machine". Spesimen pengujian tarik dibentuk menurut standar ASTM D 638-03 yang ditunjukkan pada gambar 1 sebagai berikut:

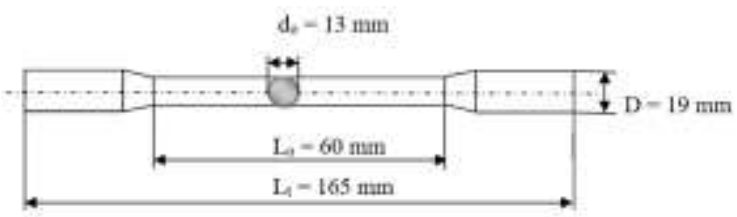

Gambar 1. Dimensi benda pengujian tarik ASTM D $638-03$ [17]

Besarnya nilai modulus elastisitas baut baja ST-60 yang juga merupakan perbandingan antara tegangan dan regangan pada daerah proporsional dapat dihitung dengan persamaan:

$$
\mathrm{E}=\sigma_{R} / \varepsilon
$$

Dimana: $\mathrm{E}=$ Modulus elastisitas tarik (MPa)

$\sigma_{t r}=$ Kekuatan tarik (MPa)

$\varepsilon=$ Regangan $(\mathrm{mm} / \mathrm{mm})$

Tegangan nominal maksimum yang ditahan oleh batang uji baut baja ST-60 sebelum patah disebut tegangan tarik $\left(\sigma_{t r}\right)$, yaitu merupakan perbandingan antara beban maksimum $\left(\mathrm{F}_{\mathrm{m}}\right)$ yang dicapai selama percobaan tarik dan penampang mula-mula $\left(\mathrm{A}_{\mathrm{o}}\right)$.

$$
\begin{aligned}
\sigma_{\mathrm{tr}} & =\mathrm{F}_{\mathrm{m}} / \mathrm{A}_{\mathrm{o}} \\
\text { Dimana: } & =\text { Kekuatan tarik }(\mathrm{MPa}) \\
\sigma_{t r} & =\text { Beban maksimum }(\mathrm{N}) \\
\mathrm{F}_{\mathrm{maks}} & =\text { Penampang mula-mula } \\
\mathrm{A}_{0}= & \left(\mathrm{mm}^{2}\right)
\end{aligned}
$$

Besarnya regangan adalah jumlah pertambahan panjang karena pembebanan dibandingkan dengan panjang daerah ukur (gage length). Nilai regangan ini adalah regangan proporsional yang didapat dari garis. Proporsional pada grafik teganganregangan hasil uji tarik baut baja ST-60 [18].

$$
\varepsilon=\Delta \mathrm{L} / \mathrm{L}
$$

Dimana: $\Delta \mathrm{L}=$ pertambahan panjang $(\mathrm{mm})$

$$
\mathrm{L}=\text { panjang daerah ukur }(\mathrm{mm})
$$

Kekerasan adalah ketahanan suatu bahan terhadap deformasi permanen oleh penetrasi dari benda lain yang lebih keras. Kekerasan adalah suatu sifat bahan yang sebagian besar dipengaruhi oleh unsur unsur paduannya. Kekerasan suatu bahan merupakan sifat yang penting, karena kekerasan bahanlah yang menentukan kemudahan penggarapannya dan menentukan ketahanan ausnya [11-16].

Karbon didalam besi secara pasti mempengaruhi kualitas baja, dan kekerasan yang dibutuhkan dapat dicapai dengan perlakuan panas. Dari beberapa riset yang dilakukan, bahwa bahan akan berubah kekerasannya bila dikerjakan dengan Cold Worked. Sebelum melakukan pengujian, benda kerja harus terlebih dahulu dihaluskan permukaannya sehingga licin dan mengkilat, dan dalam pengerjaannya tidak boleh menimbulkan perubahan struktur logam yang akan diuji. Bentuk yang paling umum dalam pengujian 
kekerasan bahan adalah menggunakan pembuat lekukan (Indentor) standar yang ditekan pada permukaan benda uji. Hasil lekukan yang terjadi memberikan harga kekerasan. Harga Kekerasan tidak mempunyai standar atau skala yang mutlak, oleh karena harga kekerasan dari suatu jenis pengujian memiliki skala tersendiri, walaupun terdapat beberapa hubungan dari skala yang satu dengan skala yang lainnya $[12,13]$.

Pada metode Vickers ini dasar pengujiannya adalah digunakan indentor dari permata yang berbentuk piramida dengan bidang alas bujur sangkar dan sudut puncaknya yang khusus. Dengan memberikan beban pada logam (benda kerja) beban $\mathrm{F}$ dan diagonal bekas penekanan diukur setelah beban diangkat. Kekerasan vickers adalah suatu hasil bagi yang didapatkan dengan membagi beban yang dikenakan $\mathrm{F}$ dengan luasan bentangan pada permukaan indentasi dari benda kerja, dengan memperhatikan bentuk piramid dengan alas bujur sangkar dengan diagonal d dan mempunyai sudut puncak yang sama dengan indentor dari permata. Dasar perhitungan kekerasan vickers adalah :

$$
\begin{aligned}
\mathrm{HV} & =\frac{\text { Beban yang dikenakan }}{\text { Luasan identasi }} \\
& =\frac{2 F \sin \frac{136^{\circ}}{2}}{d^{2}}=1,854 \frac{F}{d^{2}}
\end{aligned}
$$

Pengujian komposisi logam digunakan untuk mengetahui kandungan unsur-unsur yang terdapat dalam baja dengan presentase yang berbeda-beda didalamnya. Komposisi Kimia merupakan suatu uji yang bertujuan untuk mengetahui kandungan unsur kimia yang terdapat pada logam atau baja dari benda uji baut baja ST-60. Dalam pengujian komposisi kimia klasifikasi dari baja atau specimen yang akan dilakukan harus diketahui karena menyesuaikan klasifikasi yang ada di mesin uji. Pengujian komposisi kimia dilakukan dengan menggunakan mesin uji Optical Emision Spectroscopy $(O E S)[12,13]$.

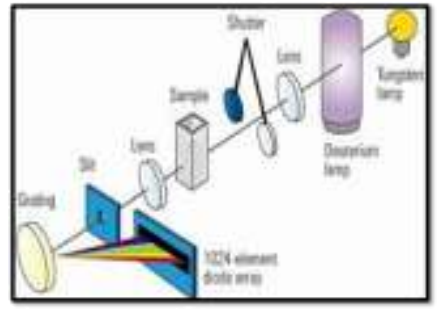

Gambar 2. Prinsip Kerja Optical Emision Spectroscopy (OES).

Pada gambar 2, menunjukkan prinsip kerja alat uji komposisi kimia yaitu Optical Emision Spectroscopy (OES) yaitu pengujian sinar radioaktif dan gas argon ditembakkan terhadap sampel, kemudian dari hasil penembakan didapatkan print out hasil uji yang terbaca pada layar computer (gambar 3).

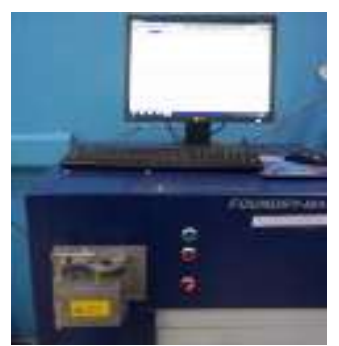

Gambar 3. Mesin Optical Emision Spectroscopy (OES).

Analisis komposisi kimia ini dapat kita gunakan untuk mengetahui kadar karbon pada bahan baut baja ST-60 yang kita gunakan dan unsur-unsur lainnya, apakah baja tersebut masuk dalam jenis baja karbon rendah (low karbon steel), baja karbon sedang (medium carbon steel), dan baja karbon tinggi (high carbon steel) atau malah masuk ke dalam kategori baja paduan.

\section{Metode Penelitian}

Metode yang dilakukan pada penelitian ini adalah metode eksperimen, dimana bahan atau material yang digunakan adalah bahan baut ST-60. Bentuk sampel untuk pengujian tarik mengacu standar ASTM D 638-03, sedangkan untuk pengujian komposisi kimia berdasarkan standar mesin yaitu $\varnothing 16$ $\mathrm{mm}$ x $20 \mathrm{~mm}$. Pada penelitian ini sampel dibuat masing-masing 5 sampel dengan jenis perlakuan panas pada proses 
normalizing dan proses hardening quenching pada temperatur $0^{\circ} \mathrm{C}, 800^{\circ} \mathrm{C}$, $850^{\circ} \mathrm{C}, 900^{\circ} \mathrm{C}, 950^{\circ} \mathrm{C}$ dan $1000^{\circ} \mathrm{C}$.

Pengujian yang akan dilakukan yaitu pengujian tarik, pengujian kekerasan dan uji komposisi kimia dengan tempat pengujian sampel dilakukan di Laboratorium Pengujian Bahan Jurusan Teknik Mesin Politeknik Negeri Pontianak. Adapun tahap-tahap penelitian yang dilakukan adalah sebagai berikut:

1. Menyediakan bahan baut ST-60 sesuai dengan jumlah sampel yang akan dibuat.

2. Pembuatan sampel pengujian tarik dengan ukuran sesuai standar ASTM D 638-03 (gambar 4), pengujian kekerasan dan pengujian komposisi kimia sesuai standar mesin yang ukuran dimensi Ø16 mm x $20 \mathrm{~mm}$ (gambar 5). Jumlah sampel masing-masing pengujian sebanyak 60 sampel.

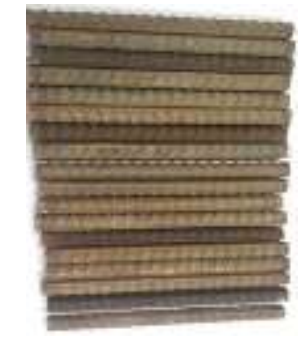

Gambar 4. Sampel uji tarik.

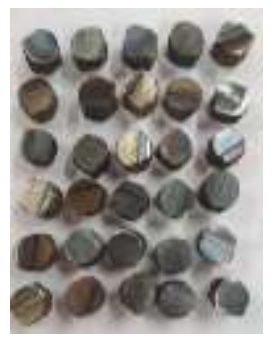

Gambar 5. Sampel uji kekerasan dan komposisi kimia.

3. Melakukan pemanasan sampel pengujian tarik, kekerasan dan komposisi kimia pada dapur pemanas (gambar 6) dengan dua perlakuan yaitu proses normalizing dan proses hardening quenching pada temperatur $800{ }^{0} \mathrm{C}, 850{ }^{0} \mathrm{C}$, $900{ }^{\circ} \mathrm{C}, 950{ }^{\circ} \mathrm{C}$ dan $1000{ }^{\circ} \mathrm{C}$.

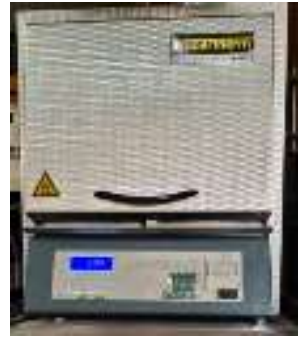

Gambar 6. Dapur pemanas.

4. Melakukan pengujian sampel bahan baut ST-60 dengan mesin uji tarik (gambar 7), mesin uji kekerasan dengan metode Vickers (gambar 8) dan mesin uji komposisi kimia (mesin Optical Emision Spectroscopy gambar 9).

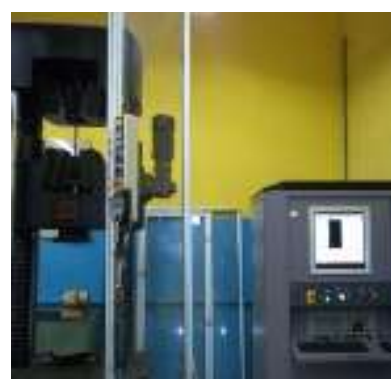

Gambar 7. Mesin uji tarik.

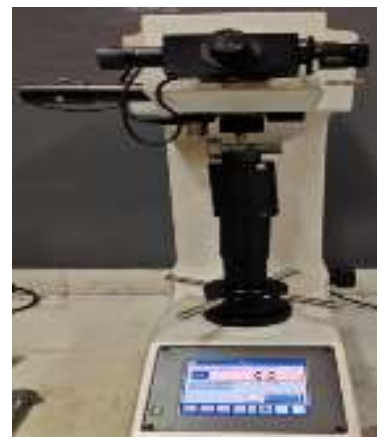

Gambar 8. Mesin uji kekerasan.

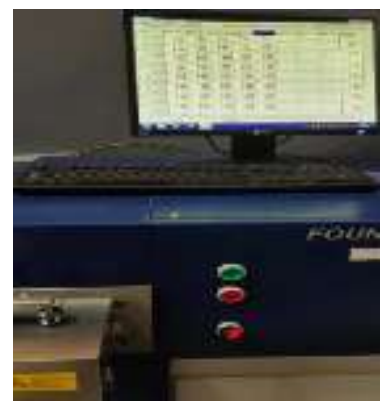

Gambar 9. Mesin uji komposisi kimia.

5. Pengambilan data dan menganalisa dari hasil pengujian. 


\section{Hasil dan Pembahasan}

Pada pengujian tarik sampel yang dibuat sebanyak 55 buah dan material yang digunakan adalah bahan baut ST-60 dengan dimensi sampel sesuai standar uji tarik ASTM D 638-03 dan dilakukan proses normalizing dan proses hardening quenching. Sampel dipanaskan didapur pemanas dengan suhu $800^{\circ} \mathrm{C}, 850^{\circ} \mathrm{C}$, $900^{\circ} \mathrm{C}, \quad 950^{\circ} \mathrm{C}$ dan $1000^{\circ} \mathrm{C}$ dan setiap temperatur suhu tercapai ditahan selama 30 menit. Setiap temperatur 10 sampel yang dipanaskan dan kemudian 5 buah didinginkan pada udara dan 5 buah didinginkan dengan oli bekas. Kemudian dilakukan pengujian tarik dan datanya dapat dilihat pada tabel 1 dan tabel 2 sebagai berikut.

Tabel 1. Data pengujian tarik bahan baut ST-60 dengan pendingin udara.

\begin{tabular}{|c|c|c|c|c|}
\hline \multirow[t]{2}{*}{$\begin{array}{l}\text { Specimen } \\
\text { Number }\end{array}$} & \multirow{2}{*}{$\begin{array}{c}\text { Upper } \\
\text { Yield } \\
\text { Strengt } \\
h\left(U_{Y S}\right) \\
(M P a)\end{array}$} & \multirow{2}{*}{$\begin{array}{c}\text { Tensile } \\
\text { Strengt } \\
h\left(\sigma_{m a k}\right) \\
(M P a)\end{array}$} & $\begin{array}{c}\text { Elongatio } \\
n \text { After } \\
\text { Fracture }\end{array}$ & \multirow{2}{*}{$\begin{array}{c}\text { Reductio } \\
\text { n of Area } \\
(Z)(\%)\end{array}$} \\
\hline & & & $(\varepsilon)(\%)$ & \\
\hline \multicolumn{5}{|c|}{ Tanpa dipanaskan $\left(0{ }^{0} \mathrm{C}\right)$} \\
\hline Rata-rata & 466,10 & 616,41 & 16,85 & 35,39 \\
\hline \multicolumn{5}{|c|}{ Tanpa dipanaskan $\left(800^{\circ} \mathrm{C}\right)$} \\
\hline Rata-rata & 341,01 & 451,04 & 17,02 & 35,04 \\
\hline \multicolumn{5}{|c|}{ Tanpa dipanaskan $\left(850{ }^{\circ} \mathrm{C}\right)$} \\
\hline Rata-rata & 302,96 & 401,06 & 17,19 & 34,69 \\
\hline \multicolumn{5}{|c|}{ Tanpa dipanaskan $\left(900{ }^{\circ} \mathrm{C}\right)$} \\
\hline Rata-rata & 262,78 & 344,91 & 17,36 & 34,33 \\
\hline \multicolumn{5}{|c|}{ Tanpa dipanaskan $\left(950^{\circ} \mathrm{C}\right)$} \\
\hline Rata-rata & 254,64 & 335,76 & 17,53 & 33,98 \\
\hline \multicolumn{5}{|c|}{ Tanpa dipanaskan $\left(1000{ }^{\circ} \mathrm{C}\right)$} \\
\hline Rata-rata & 235,32 & 310,53 & 17,69 & 33,62 \\
\hline
\end{tabular}

Tabel 2. Data pengujian tarik bahan baut ST-60 dengan pendingin oli bekas.

\begin{tabular}{|c|c|c|c|c|}
\hline $\begin{array}{c}\text { Specimen } \\
\text { Number }\end{array}$ & $\begin{array}{c}\text { Upper } \\
\text { Yield } \\
\text { Strengt } \\
h\left(U_{Y S}\right) \\
(M P a)\end{array}$ & $\begin{array}{c}\text { Tensile } \\
\text { Strengt } \\
h\left(\sigma_{\text {mak }}\right) \\
(M P a)\end{array}$ & $\begin{array}{c}\text { Elongatio } \\
n \text { After } \\
\text { Fracture } \\
(\varepsilon)(\%)\end{array}$ & $\begin{array}{c}\text { Reductio } \\
\text { n of Area } \\
(Z)(\%)\end{array}$ \\
\hline \multicolumn{5}{|c|}{ Tanpa dipanaskan $\left(0{ }^{\circ} \mathrm{C}\right)$} \\
\hline Rata-rata & 466,10 & 616,41 & 16,85 & 35,39 \\
\hline \multicolumn{5}{|c|}{ Dipanaskan suhu $\left(800^{\circ} \mathrm{C}\right)$} \\
\hline Rata-rata & 489,40 & 647,23 & 16,68 & 34,69 \\
\hline \multicolumn{5}{|c|}{ Dipanaskan suhu $\left(8500^{\circ} \mathrm{C}\right)$} \\
\hline Rata-rata & 508,04 & 671,89 & 16,51 & 34,33 \\
\hline \multicolumn{5}{|c|}{ Diipanaskan suhu $\left(900{ }^{\circ} \mathrm{C}\right)$} \\
\hline Rata-rata & 526,69 & 696,55 & 16,35 & 33,98 \\
\hline \multicolumn{5}{|c|}{ Dipanaskan suhu $\left(950{ }^{\circ} \mathrm{C}\right)$} \\
\hline Rata-rata & 531,35 & 702,71 & 16,18 & 33,62 \\
\hline \multicolumn{5}{|c|}{ Dipanaskan suhu $\left(1000{ }^{\circ} \mathrm{C}\right)$} \\
\hline Rata-rata & 559,32 & 739,70 & 16,01 & 33,27 \\
\hline
\end{tabular}

Berdasarkan tabel 1 dan tabel 2 maka dapat dibuat grafik hubungan kekuatan tarik dan temperatur dengan pendingin udara dan grafik hubungan kekuatan tarik dengan temperatur dengan pendingin oli bekas dapat dilihat pada gambar 10 sebagai berikut:

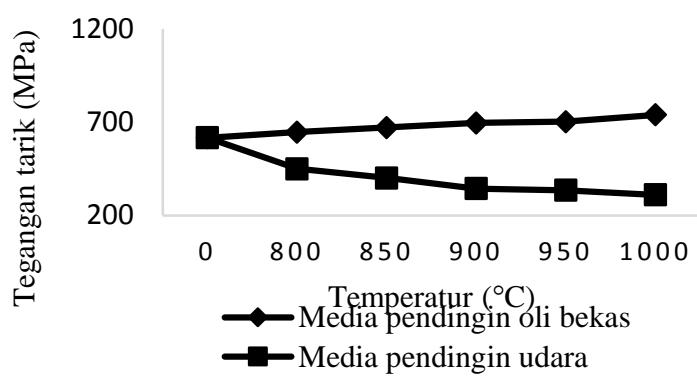

Gambar 10. Grafik hubungan kekuatan tarik dan temperatur.

Pada pengujian kekerasan vickers sampel bahan baut ST-60 dibuat sebanyak 55 buah dengan ukuran dimensi $\emptyset 16 \mathrm{~mm} x$ $20 \mathrm{~mm}$ sesuai standar mesin. Sampel dilakukan proses normalizing dan proses hardening quenching dipanaskan didapur pemanas masing-masing 10 buah dengan suhu $800^{\circ} \mathrm{C}, 850^{\circ} \mathrm{C}, 900^{\circ} \mathrm{C}, 950^{\circ} \mathrm{C}$ dan $1000^{\circ} \mathrm{C}$ dan setiap temperatur suhu tercapai ditahan selama 30 menit. Sampel yang telah dipanaskan pada masing-masing temperatur, 5 buah didinginkan pada udara dan 5 buah didinginkan dengan oli bekas. Kemudian dilakukan kekerasan vickers dan datanya dapat dilihat pada tabel 3 dan tabel 4.

Tabel 3. Data kekerasan vickers bahan baut ST-60 dengan pendingin udara.

\begin{tabular}{ccccccc}
\hline & \multicolumn{6}{c}{ Kekerasan Vickers (HV) } \\
\cline { 2 - 7 } $\begin{array}{c}\text { Nomor } \\
\text { Sampel }\end{array}$ & $\begin{array}{c}\text { Tanpa } \\
\text { Dipanask } \\
\text { an }\end{array}$ & $\begin{array}{c}\text { Dipa } \\
\text { nask } \\
\text { an }\end{array}$ & $\begin{array}{c}\text { Dipa } \\
\text { nask } \\
\text { an }\end{array}$ & $\begin{array}{c}\text { Dipa } \\
\text { nask } \\
\text { an }\end{array}$ & $\begin{array}{c}\text { Dipa } \\
\text { nask } \\
\text { an }\end{array}$ & $\begin{array}{c}\text { Dipa } \\
\text { nask } \\
\text { an }\end{array}$ \\
\hline $\begin{array}{c}\left(0{ }^{0} \mathrm{C}\right) \\
\begin{array}{c}\text { Rata- } \\
\text { Rata }\end{array}\end{array}$ & $\begin{array}{c}800 \\
\left.{ }^{0} \mathrm{C}\right)\end{array}$ & $\begin{array}{c}(850 \\
\left.{ }^{0} \mathrm{C}\right)\end{array}$ & $\begin{array}{c}(900 \\
\left.{ }^{0} \mathrm{C}\right)\end{array}$ & $\begin{array}{c}(950 \\
\left.{ }^{0} \mathrm{C}\right)\end{array}$ & $\begin{array}{c}(100 \\
\left.0{ }^{\circ} \mathrm{C}\right)\end{array}$ \\
\hline
\end{tabular}

Tabel 4. Data kekerasan vickers bahan baut ST-60 dengan pendingin oli bekas.

\begin{tabular}{ccccccc}
\hline & \multicolumn{6}{c}{ Kekerasan Vickers (HV) } \\
Nomor & Tanpa & Dipa & Dipa & Dipa & Dipa & Dipa \\
Sampe & Dipanask & naska & naska & naska & naska & naska \\
1 & an & $\mathrm{n}$ & $\mathrm{n}$ & $\mathrm{n}$ & $\mathrm{n}$ & $\mathrm{n}$ \\
\cline { 2 - 7 } & \multirow{2}{*}{$\left(0^{\circ} \mathrm{C}\right)$} & $(800$ & $(850$ & $(900$ & $(950$ & $(100$ \\
& & $\left.{ }^{0} \mathrm{C}\right)$ & $\left.{ }^{0} \mathrm{C}\right)$ & $\left.{ }^{0} \mathrm{C}\right)$ & $\left.{ }^{0} \mathrm{C}\right)$ & $\left.0{ }^{\circ} \mathrm{C}\right)$ \\
\hline Rata- & \multirow{2}{*}{109,10} & 110,2 & 113,3 & 117,4 & 119,9 & 128,3 \\
Rata & & 4 & 5 & 9 & 1 & 9 \\
\hline
\end{tabular}


Dari data tabel 3 dan tabel 4 maka dapatlah dibuat grafik hubungan kekerasan vickers dan temperatur dengan pendingin udara (garis warna merah) dan grafik hubungan kekerasan vickers dengan temperatur dengan pendingin oli bekas (garis warna biru) dapat dilihat pada gambar 11 sebagai berikut:

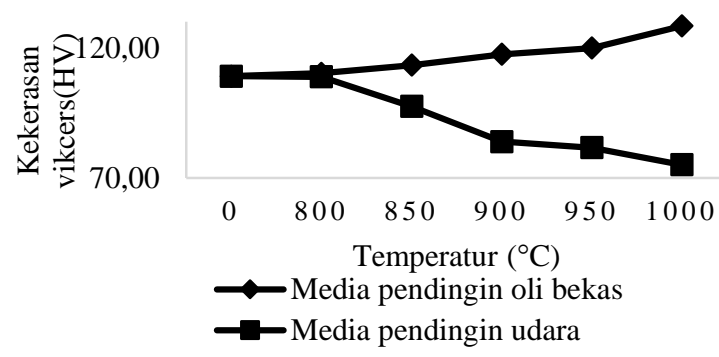

Gambar 11. Grafik hubungan kekerasan vickers dan temperatur.

Pada pengujian komposisi kimia sampel bahan baut ST-60 dibuat sebanyak 55 buah dengan ukuran dimensi $\varnothing 16 \mathrm{~mm}$ x $20 \mathrm{~mm}$ sesuai standar mesin. Sampel dilakukan proses normalizing dan proses hardening quenching dengan dipanaskan didapur pemanas masing-masing 10 buah dengan suhu $800^{\circ} \mathrm{C}, 850^{\circ} \mathrm{C}, 900^{\circ} \mathrm{C}, 950^{\circ} \mathrm{C}$ dan $1000^{\circ} \mathrm{C}$ dan setiap temperatur suhu tercapai ditahan selama 30 menit. Sampel yang telah dipanaskan pada masing-masing temperatur, 5 buah didinginkan pada udara dan 5 buah didinginkan dengan oli bekas. Kemudian dilakukan pengujian komposisi kimia dan datanya dapat dilihat pada tabel 5 dan tabel 6.

Tabel 5. Data pengujian komposisi kimia bahan baut ST-60 dengan pendingin udara.

\begin{tabular}{|c|c|c|c|c|c|c|c|}
\hline \multirow{2}{*}{$\begin{array}{l}\text { Specimen } \\
\text { Number }\end{array}$} & \multicolumn{7}{|c|}{ Komposisi Kimia (\%) } \\
\hline & $\mathrm{Fe}$ & $\mathrm{C}$ & $\mathrm{Si}$ & $\mathrm{Mn}$ & $\mathrm{P}$ & $\mathrm{S}$ & $V$ \\
\hline \multicolumn{8}{|c|}{ Tanpa dipanaskan $\left(0^{\circ} \mathrm{C}\right)$} \\
\hline \multirow{2}{*}{ Rata-rata } & 97,9 & 0,3 & 0,3 & 1,0 & 0,02 & 0,01 & 0,00 \\
\hline & 80 & 91 & 17 & 24 & 84 & 55 & 75 \\
\hline \multicolumn{8}{|c|}{ Dipanaskan $\left(800^{\circ} \mathrm{C}\right)$} \\
\hline \multirow{2}{*}{ Rata-rata } & 98,1 & 0,2 & 0,2 & 1,0 & 0,02 & 0,01 & 0,00 \\
\hline & 60 & 96 & 90 & 18 & 80 & 51 & 73 \\
\hline \multicolumn{8}{|c|}{ Dipanaskan $\left(850^{\circ} \mathrm{C}\right)$} \\
\hline \multirow{2}{*}{ Rata-rata } & 98,2 & 0,2 & 0,2 & 0,9 & 0,02 & 0,01 & 0,00 \\
\hline & 60 & 95 & 65 & 84 & 77 & 70 & 58 \\
\hline \multicolumn{8}{|c|}{ Dipanaskan $\left(900^{\circ} \mathrm{C}\right)$} \\
\hline \multirow{2}{*}{ Rata-rata } & 98,2 & 0,2 & 0,2 & 0,9 & 0,02 & 0,01 & 0,00 \\
\hline & 20 & 88 & 62 & 80 & 71 & 82 & 60 \\
\hline \multicolumn{8}{|c|}{ Dipanaskan $\left(950^{\circ} \mathrm{C}\right)$} \\
\hline \multirow{2}{*}{ Rata-rata } & 98,2 & 0,2 & 0,2 & 0,9 & 0,03 & 0,01 & 0,00 \\
\hline & 80 & 58 & 61 & 84 & 00 & 81 & 69 \\
\hline \multicolumn{8}{|c|}{ Dipanaskan $\left(1000^{\circ} \mathrm{C}\right)$} \\
\hline \multirow{2}{*}{ Rata-rata } & 98,3 & 0,2 & 0,3 & 1,0 & 0,02 & 0,01 & 0,00 \\
\hline & 00 & 02 & 80 & 06 & 98 & 88 & 66 \\
\hline
\end{tabular}

Tabel 6. Data pengujian komposisi kimia bahan baut ST-60 dengan pendingin oli bekas.

\begin{tabular}{|c|c|c|c|c|c|c|c|}
\hline \multirow{2}{*}{$\begin{array}{c}\text { Specimen } \\
\text { Number }\end{array}$} & \multicolumn{7}{|c|}{$\begin{array}{c}\text { Komposisi Kimia (\%) Dengan Perendaman Oli } \\
\text { Bekas }\end{array}$} \\
\hline & $\mathrm{Fe}$ & $\mathrm{C}$ & $\mathrm{Si}$ & $\mathrm{Mn}$ & $\mathrm{P}$ & $\mathrm{S}$ & $\mathrm{V}$ \\
\hline \multicolumn{8}{|c|}{ Tanpa dipanaskan $\left(0^{0} \mathrm{C}\right)$} \\
\hline \multirow{2}{*}{ Rata-rata } & 97,9 & 0,39 & 0,31 & 1,02 & 0,02 & 0,01 & 0,00 \\
\hline & 80 & 1 & 7 & 4 & 84 & 55 & 75 \\
\hline \multicolumn{8}{|c|}{ Dipanaskan $\left(800{ }^{\circ} \mathrm{C}\right)$} \\
\hline \multirow{2}{*}{ Rata-rata } & 98,1 & 0,40 & 0,48 & 0,79 & 0,02 & 0,02 & 0,01 \\
\hline & 20 & 2 & 8 & 9 & 45 & 53 & 62 \\
\hline \multicolumn{8}{|c|}{ Dipanaskan $\left(850^{\circ} \mathrm{C}\right)$} \\
\hline \multirow{2}{*}{ Rata-rata } & 97,8 & 0,42 & 0,31 & 0,57 & 0,02 & 0,02 & 0,01 \\
\hline & 80 & 3 & 2 & 7 & 80 & 09 & 44 \\
\hline \multicolumn{8}{|c|}{ Dipanaskan $\left(900{ }^{\circ} \mathrm{C}\right)$} \\
\hline \multirow{2}{*}{ Rata-rata } & 97,7 & 0,43 & 0,32 & 0,59 & 0,02 & 0,02 & 0,01 \\
\hline & 80 & 9 & 9 & 7 & 77 & 62 & 44 \\
\hline \multicolumn{8}{|c|}{ Dipanaskan $\left(950^{\circ} \mathrm{C}\right)$} \\
\hline \multirow{2}{*}{ Rata-rata } & 97,9 & 0,44 & 0,28 & 0,56 & 0,03 & 0,02 & 0,01 \\
\hline & 20 & 2 & 0 & 1 & 22 & 64 & 53 \\
\hline \multicolumn{8}{|c|}{ Dipanaskan $\left(1000{ }^{\circ} \mathrm{C}\right)$} \\
\hline \multirow{2}{*}{ Rata-rata } & 97,8 & 0,45 & 0,30 & 0,58 & 0,03 & 0,02 & 0,04 \\
\hline & 60 & 6 & 5 & 5 & 08 & 41 & 30 \\
\hline
\end{tabular}

Berdasarkan data tabel 5 dan tabel 6 maka dapatlah dibuat grafik hubungan kandungan karbon dan temperatur dengan pendingin udara (garis warna merah) dan grafik kandungan karbon dengan temperatur dengan pendingin oli bekas (garis warna hijau) dapat dilihat pada gambar 12 sebagai berikut:

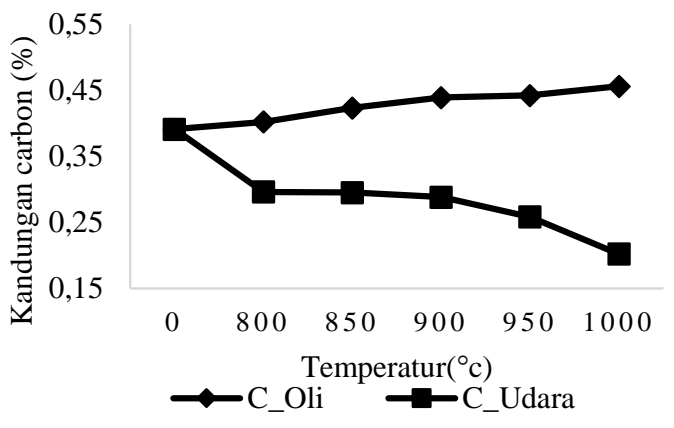

Gambar 12. Grafik hubungan kandungan karbon dan temperatur.

Berdasarkan data pengujian tarik bahan baut ST-60 pada tabel 1 dan tabel 2 serta gambar grafik 11, maka dapat dilihat bahwa pada proses normalizing yaitu dengan meningkatnya temperatur pemanasan dan didinginkan dengan udara, kekuatan tarik bahan baut ST-60 terjadi penurunan dari kekuatan tarik awal bahan yang tidak dilakukan proses normalizing. Adapun besaran penurunan kekuatan tarik 
bahan baut ST-60 dari temperatur $800{ }^{0} \mathrm{C}$ sampai $1000{ }^{\circ} \mathrm{C}$ adalah rata-rata penurunan $230,78 \mathrm{~N} / \mathrm{mm}^{2}$ atau $50 \%$ dari kekuatan tarik awal bahan baut ST-60 yaitu sebesar $466,10 \mathrm{~N} / \mathrm{mm}^{2}$. Sedangkan kekuatan tarik bahan baut ST-60 dengan proses hardening quenching dengan peningkatan temperatur pemanasan dan didinginkan dengan oli bekas, kekuatan tarik bahan baut ST-60 terjadi peningkatan. Adapun besaran peningkatan kekuatan tarik bahan baut ST60 dari temperatur $800{ }^{0} \mathrm{C}$ sampai $1000{ }^{0} \mathrm{C}$ adalah rata-rata naik $93,22 \mathrm{~N} / \mathrm{mm}^{2}$ atau 20 $\%$ dari kekuatan tarik awal bahan baut ST60.

Berdasarkan tabel 3 dan tabel 4 serta grafik 12 dapat dilihat bahwa dengan proses normalizing dengan meningkatnya temperatur pemanasan dan didinginkan dengan udara, kekerasan vickers bahan baut ST-60 terjadi penurunan dari kekerasan Vickers awal bahan yang tidak dilakukan proses normalizing. Adapun besaran penurunan kekerasan Vickers bahan baut ST-60 dari temperatur $800{ }^{\circ} \mathrm{C}$ sampai 1000 ${ }^{0} \mathrm{C}$ adalah rata-rata penurunan setiap temperatur sebesar 33,99 $\mathrm{HV}$ atau $31 \%$ dari kekerasan Vickers awal bahan baut yaitu sebesar 109,10 HV. Sedangkan kekerasan Vickers bahan baut ST-60 dengan proses hardening quenching dengan peningkatan temperatur pemanasan dan didinginkan dengan oli bekas, kekerasan vickers bahan baut ST-60 terjadi peningkatan dari kekerasan vickers awal bahan. Adapun besaran peningkatan kekerasan vickers rata-rata bahan tersebut dari temperatur $800{ }^{0} \mathrm{C}$ sampai $1000{ }^{0} \mathrm{C}$ adalah 19,29 $\mathrm{HV}$ atau naik $18 \%$ dari kekerasan vickers awal bahan baut ST-60.

Kemudian untuk pengujian komposisi kimia dengan berdasarkan tabel 5 dan tabel 6 serta grafik 13 menunjukkan bahwa pada proses normalizing dengan meningkatnya temperatur pemanasan dan didinginkan dengan udara, kandungan kadar karbon bahan baut ST-60 terjadi penurunan kadar karbon dibanding dengan tidak dilakukan proses normalizing. Adapun besaran penurunan kandungan kadar karbon bahan baut ST-60 dari temperatur $800{ }^{\circ} \mathrm{C}$ sampai $1000{ }^{\circ} \mathrm{C}$ adalah sebesar 0,19 atau $48 \%$ dari kandungan kadar karbon tidak tidak dilakukan proses normalizing yaitu sebesar 0,391. Sedangkan kandungan kadar karbon bahan baut ST-60 dengan proses hardening quenching dengan peningkatan temperatur pemanasan dan didinginkan dengan oli bekas, kandungan kadar karbon bahan baut ST-60 terjadi peningkatan dari kandungan kadar karbon tidak dilakukan proses normalizing. Adapun besaran peningkatan kandungan kadar karbon bahan baut ST-60 dari temperatur $800{ }^{0} \mathrm{C}$ sampai $1000{ }^{0} \mathrm{C}$ adalah sebesar 0,06 atau naik $17 \%$ dari kandungan kadar karbon tidak dilakukan proses normalizing.

Berdasarkan data-data di atas menunjukkan bahwa hasil pengujian kekuatan tarik, kekerasan Vickers dan komposisi kimia dengan proses normalizing bahan baut ST-60 dipanaskan masing-masing pada suhu $800{ }^{\circ} \mathrm{C}, 850{ }^{\circ} \mathrm{C}$, $900{ }^{\circ} \mathrm{C}, 950{ }^{0} \mathrm{C}$ dan $1000{ }^{\circ} \mathrm{C}$ setiap suhu tercapai dihentikan dengan 30 menit agar terjadi transformasi fasa pada seluruh bagian material, kemudian dilakukan proses pendinginan menggunakan udara, menunjukkan kekuatan mekanik dan kandungan kadar karbon menurun yaitu untuk kekuatan tarik sebesar 50\%, kekerasan Vickers $31 \%$ dan kandungan kadar karbon $48 \%$. Sedangkan dengan proses hardening bahan baut ST-60 proses sama dengan proses normalizing dipanaskan hingga mencapai suhu spesifik dan dihentikan 30 menit, kemudian dilakukan proses quenching yaitu bahan baut yang dipanaskan dan didinginkan secara cepat atau dicelup pada oli bekas, menunjukkan peningkatan kekuatan mekanik dan kandungan kadar karbon yaitu untuk kekuatan tarik sebesar 20\%, kekerasan Vickers $18 \%$ dan kandungan kadar karbon $17 \%$. Jadi dengan proses normalizing yaitu pengaruh temperatur panas dan media pendingin udara, mengurangi kekuatan mekanik dan kandungan kadar karbon dari bahan baut 
ST-60.. Sedangkan dengan proses hardening dan dilanjutkan dengan proses quenching, temperatur panas dan media pendingin oli bekas, dapat meningkatkan kekuatan mekanik dan kadar kandungan karbon.

Jadi untuk menjaga agar kekuatan mekanik dan mikro struktur bahan baut ST60 tidak pengaruh terhadap temperatur panas, maka perlu dilakukan pemberian atau dipoles dengan oli bekas. Pemolesan oli bekas ini dilakukan setiap baut bekerja pada temperatur panas, sehingga dapat mengatasi penurunan kekuatan mekanik dan perubahan mikro struktur bahan baut tersebut.

\section{Kesimpulan}

Berdasarkan dari hasil penelitian ini dapatlah disimpulkan bahwa pengujian kekuatan mekanik dan mikro struktur (komposisi kimia) bahan baut ST-60 pada proses normalizing untuk kekuatan tarik menurun rata-rata sebesar $230,78 \mathrm{~N} / \mathrm{mm}^{2}$ atau 50\%, kekerasan Vickers menurun ratarata sebesar 33,99 $\mathrm{HV}$ atau $31 \%$ dan kandungan kadar karbon menurun rata-rata sebesar 0,19 atau $48 \%$ dari tidak dilakukan proses normalizing. Sedangkan kekuatan mekanik dan mikro struktur (komposisi kimia) bahan baut ST-60 pada proses hardening quenching, kekuatan tarik ratarata naik sebesar 93,22 N/mm2 atau $20 \%$, kekerasan Vickers rata-rata naik sebesar $19,29 \mathrm{HV}$ atau $18 \%$ dan kandungan kadar karbon rata-rata naik sebesar 0,06 atau naik $17 \%$ dari tidak dilakukan proses hardening quenching.

Untuk mengatasi terjadi penurunan kekuatan mekanik dan perubahan mikro struktur pada bahan baut ST-60 akibat temperatur panas maka proses hardening quenching dapat diterapkan, yaitu pemberian dengan pemolesan dengan oli bekas setelah baut bekerja pada temperatur panas.

\section{Ucapan terimakasih}

Ucapan terimakasih disampaikan kepada pimpinan Politeknik Negeri
Pontianak dan Struktural Jurusan Teknik Mesin yang telah membantu dalam pendanaan dan proses penelitian yang dilakukan hingga penulisan dalam Jurnal Turbo ini. Dan tak lupa juga ucapan terima kasih kepada rekan sejawat dan mahasiswa Jurusan Teknik Mesin serta pengurus Jurnal Turbo yang telah membantu dalam proses penulisan hingga diterbitkan penulisan ini.

\section{Referensi}

[1] Timings RL, 1998, Engineering Materials, Volume-I, 2nd Edition Addison Wesley Longman Limited.

[2] Faupel, H Joseph, Fisher, E Franklin, 1981, Engineering Design, 2nd ed., John Willey and Sons, New York.

[3] Marrow J, 2009, The Materials Science Internet Microscope, UMIST and University of Manchester, www.umist.ac.uk/matsci.

[4] Anonymous, 2010, Logam Besi. Diakses tanggal 12 April 2011. http://www.mailarchive.com/palanta @ minang.rantaunet.org/msg15305.h tml.

[5] Purwaningrum, Yustiasih, 2006, Karakterisasi Sifat Fisis dan Mekanis Sambungan Las SMAW Baja A-287 Sebelum dan Sesudah $P W H T$. Jurnal TEKNOIN. Vol. 11, No. 3. Hal: 233-242.

[6] Amanto, Hari, dan Daryanto, 2003, Ilmu Bahan. Jakarta: PT. Bumi Aksara.

[7] Dietser, George E, Sriatie Djaprie, 1987, Metalurgi Mekanik Jilid 1 Edisi Ketiga. Jakarta: Erlangga.

[8] Malau, Viktor dan Adhika Widyaparaga, 2008, Pengaruh Perlakuan Panas Quench dan Temper Terhadap Laju Keausan, Ketangguhan Impak,kekuatan tarik dan kekerasan baja XW 42 untuk keperluan Cetakan Keramik. Jurnal Media Teknik. No 2. Hal: 186-192. 
[9] Sudjana, Hardi, 2008, Teknik Pengecoran Logam. Jakarta: Direktorat Pembinaan Sekolah Menengah Kejuruan.

[10] Surdia T \& Saito S, 1999, Pengetahuan Bahan Teknik. Jakarta : PT. Pradnya Paramita.

[11] Drihandono, S., \& Budiyanto, E. (2017). Pengaruh Temperatur Tuang, Temperatur Cetakan, dan Tekanan Pada Pengecoran Bertekanan (High Pressure Die Casting/HPDC) Terhadap Kekerasan dan Struktur Mikro Aluminium Paduan Silikon (Al-Si 7, 79\%). Turbo: Jurnal Program Studi Teknik Mesin, 5(1).

[12] Budiyanto, E., Nugroho, E., \& Masruri, A. (2017). Pengaruh diameter filler dan arus pada pengelasan TIG terhadap kekuatan tarik dan struktur mikro pada baja karbon rendah. Turbo: Jurnal Program Studi Teknik Mesin, 6(1).

[13] Wahyudi, T. C., \& Budiyanto, E. (2021). Variasi temperatur pada proses squeeze casting berbahan magnesium semi solid terhadap hasil kekerasan. ARMATUR: Artikel Teknik Mesin \& Manufaktur, 2(1), 19-26.

[14] Indratmoko, A. L., Nugroho, E., Asroni, A., \& Budiyanto, E. (2020). Pengaruh Holding Time dan media pendingin pada proses quenching terhadap kekerasan dan kekuatan Impact pegas daun sebagai alternatif pengganti pisau slicer penuai tebu. ARMATUR: Artikel Teknik Mesin \& Manufaktur, 1(2), 82-95.

[15] Budiyanto, E., Nugroho, E., \& Putra, Y. G. K. (2020). Electrical Discharge Machine (EDM): evaluasi nilai kekasaran permukaan benda kerja pengaruh variasi kuat arus listrik dan kekerasan material. Turbo: Jurnal Program Studi Teknik Mesin, 9(1).

[16] Nugroho, E., Budiyanto, E., \& Suseno, E. B. (2021). Experimental evaluation of mechanical properties of friction welded mild steel. Turbo: Jurnal Program Studi Teknik Mesin, 10(1).

[17] Book Standard ASTM D638-03 (2003), Standard Test Method For Tensile Properties Of Plastics. ASTM International.

[18] Book Standard ASTM D638-03 (2003), Standard Test Method For Tensile Properties of Plastics. ASTM International. 